\title{
DENDROFLORA PARKU PAŁACOWEGO W SIEDLCU (WOJEWÓDZTWO WIELKOPOLSKIE)
}

\author{
DENDROFLORA OF THE PALACE PARK IN SIEDLEC \\ (GREATER POLAND VOIVODESHIP)
}

\author{
Wojciech Antkowiak, MieczysŁaw Czekalski
}

\begin{abstract}
W. Antkowiak, Katedra Botaniki, Uniwersytet Przyrodniczy w Poznaniu, ul. Wojska Polskiego 71 C, 60-656 Poznań, Poland, e-mail: wojciech.antkowiak@up.poznan.pl

M. Czekalski, Katedra Roślin Ozdobnych, Uniwersytet Przyrodniczy w Poznaniu, ul. Dąbrowskiego 159, 60-594 Poznań, Poland, e-mail: m.czekalski@op.pl
\end{abstract}

(Received: September 15, 2018. Accepted: September 30, 2018)

\begin{abstract}
The park at Siedlec was established in the early 20th century. It is 6.36 ha, with 85 species and cultivars trees and shrubs. Especially noteworthy are maidenhair tree (Ginkgo biloba) $287 \mathrm{~cm}$ circumference, many trees of hedge maple (Acer campestre), and another trees and shrubs.
\end{abstract}

KEY WORDS: palace landscape park, trees and shrubs, Siedlec, Wielkopolska

\section{WSTĘP}

W przeszłości w rozwiniętej rolniczo Wielkopolsce liczne były dwory i pałace oraz towarzyszące im parki. Mimo że wiele parków przestało już istnieć, to znaczna ich część, $\mathrm{w}$ różnym stopniu zachowania i utrzymania, przetrwała do dziś. Do obiektów zadowalająco utrzymanych można zaliczyć park pałacowy w Siedlcu, w powiecie poznańskim. Inwentaryzację drzew i krzewów parku oraz projekt jego rewaloryzacji przedstawił Wilanowski (1998). Rewaloryzacja nie doczekała się jednak realizacji. W parku stwierdzono wtedy 59 taksonów drzew i krzewów. Obecnie, w 2018 roku, jest ich 85. Wynika to prawdopodobnie z nieuwzględnienia we wcześniejszej inwentaryzacji wszystkich taksonów lub z tego, że niektóre $z$ nich posadzono po 1998 roku. Pod względem liczby taksonów park w Siedlcu w porównaniu $\mathrm{z}$ większością parków wiejskich jest dość bogaty.

Park w Siedlcu został wpisany do rejestru zabytków 7 maja 1977 roku, pod numerem 1756/A, jako obiekt pałacowy o charakterze krajobrazowym $z$ elementami układu regularnego.

Przedstawione opracowanie jest kontynuacją prac o parkach wiejskich Wielkopolski, prowadzonych przez Mieczysława Czekalskiego od 1970 roku (CzEKALSKI 1970, 1988, 1999, 2000, 2002, 2012, 2013 i inne). Oprócz opisu parku w artykule podano także wykaz drzew i krzewów w zadrzewieniu przyległym do niego, które wchodziło w skład parku na samym początku jego kształtowania.

\section{METODA}

Prace terenowe będące podstawą przedstawionego opracowania wykonano w 2018 roku. Zasadniczą część publikacji, dotyczącą składu dendroflory i jej charakterystyki, poprzedzono syntetycznymi danymi o środowisku przyrodniczym obszaru, na którym jest położony Siedlec, i o jego historii. Ogólny stan parku i jego ukształtowanie opisano na podstawie obserwacji własnych. Oznaczono wszystkie taksony drzew i krzewów. Obwód pni najokazalszych drzew w obrębie danego taksonu oraz tych występujących w pojedynczych okazach mierzono na wysokości 1,3 m od powierzchni gleby. Wysokość określono wizualnie, w przybliżeniu. Nazwy drzew i krzewów przyjęto za Senetą i Dolatowskim (2003), a plan parku za WiLANOWSKIM (1998). 


\section{ŚRODOWISKO PRZYRODNICZE SIEDLCA}

Teren, na którym znajduje się Siedlec, należy do Prowincji Niż Środkowoeuropejski (31.), Podprowincji Pobrzeże Południowobałtyckie (313.), w jej części określanej jako Pojezierze Wielkopolskie (315.), makroregionu Pojezierze Wielkopolsko-Kujawskie (315.5) i mezoregionu Równina Wrzesińska (315.56). Równina ta jest prawie bezjeziorna, jedynie na południowym zachodzie występuje długa rynna kórnicka z ośmioma jeziorami. Gleba jest zróżnicowana, na piaskach występują bielicoziemy, na glinie morenowej brunatnoziemy, w płytkich zagłębieniach terenu czarne ziemie bagienne. W tutejszych lasach istnieją trzy rezerwaty. Obszar ten jest znacznie wylesiony i zmeliorowany, co objawia się niedoborem wilgoci w glebach. Opady roczne wynoszą 450-500 mm. Zdecydowanie przeważa gospodarka rolna (KonDRACKI 2002). Klimat miejscowy określa się jako umiarkowany, ale cieplejszy niż przeciętnie i suchy. Pogoda jest kształtowana przez napływające $z$ zachodu masy powietrza polarnomorskiego o zróżnicowanej temperaturze (Woś 1994). Średnia roczna temperatura powietrza wynosi $8,0^{\circ} \mathrm{C}$. Temperatura minimalna surowych zim spada do $-28^{\circ}\left(-30^{\circ} \mathrm{C}\right)$. Przeciętnie najzimniejszy jest styczeń, a najcieplejszy - lipiec. Okres wegetacyjny trwa 210-220 dni. Średnia roczna suma opadów wynosi $517 \mathrm{~mm}$. Dość często bywają lata suchsze. W latach 1951-1980 najmniejsze opady wyniosły zaledwie $339 \mathrm{~mm}$, a największe $628 \mathrm{~mm}$. W 2018 roku w Siedlcu spadło 373 mm wody. Wilgotność względna powietrza jest największa w grudniu i wynosi $89 \%$. Usłonecznienie rzeczywiste trwa średnio w roku 1550 godzin. Na omawianym obszarze dominują wiatry zachodnie (Woś 1994).

\section{ZARYS HISTORII PAŁACU I PARKU W SIEDLCU}

DurCZYKIEWICZ (1912) w opracowaniu „Dwory polskie w Wielkiem Księstwie Poznańskiem" pisał: Poznańscy kawalerowie św. Jana jerozolimskiego uzyskali Siedlec od Przemystawa I droga zamiany; odnośny akt potwierdzit w roku 1256 ks. Bolestaw. W roku 1268 pozwolit ksiaże osiedlać się w Siedlcu na prawie niemieckim. W roku 1338 biskup poznański Jan zamienit dziesięciny z Brzezia i Siedlca, pozostałości kawalerów rzeczonych, na dziesięciny z Czerlejna i Czerlejnka. W roku 1360 król Kazimierz zamienit Maniewo, Radzim i Brzeziny, Brzezie i połowę Popowa na Siedlec; odtad Siedlec przestał być wtasnościa maltańska. Jak podaje Serwis InTERnETowy Wojewódzkiej Biblioteki Publicznej i Centrum Animacji Kultury w Poznaniu „Region Wielkopolska” (2018) „...w XIV i XV w. Siedlec i okolice były własnością rycerskiego rodu Grzymalitów Siedleckich, którzy - na wyspie nieistniejącego dziś jeziora - zbudowali murowany, obronny dwór lub zamek wzmiankowany jeszcze na przełomie XVI i XVII w., kiedy tutejsze dobra należały do Grudzińskich herbu Grzymała". W latach 1770-1775 Antoni Krzycki herbu Kotwicz zbudował nową okazałą ziemiańską rezydencję. Murowany i otynkowany pałac o dwu- i trójkondygnacyjnej bryle został wzniesiony na prostokątnym rzucie $z$ dwoma bocznymi ryzalitami, z niskim parterem i znacznie wyższą, reprezentacyjną, kondygnacją piętra. Dwa duże ryzality bardziej wyodrębnione zostały w fasadzie głównej niż ogrodowej. Korpus przykryto dachem dwuspadowym, a ryzality dachami trzyspadowymi. Stan pałacu z 1912 roku $i$ jego obecny widok zaprezentowano na rycinie 1 .

Pałac przebudował w latach 1788-1790 Onufry Krzycki, który w tym celu zaangażował Jana Chrystiana Kamsetzera (1753-1795), jednego z najważniejszych artystów działających na dworze Stanisława Augusta. Tenże wraz z Dominikiem Merlinim pracował przy przebudowie Zamku Królewskiego, pałacu w Łazienkach oraz pałacu w Rogalinie. Zaprojektował także pałac w Pawłowicach, pałac Tyszkiewiczów w Warszawie czy sarkofag Jana III Sobieskiego. To właśnie Jan Ch. Kamsetzer zaprojektował założony

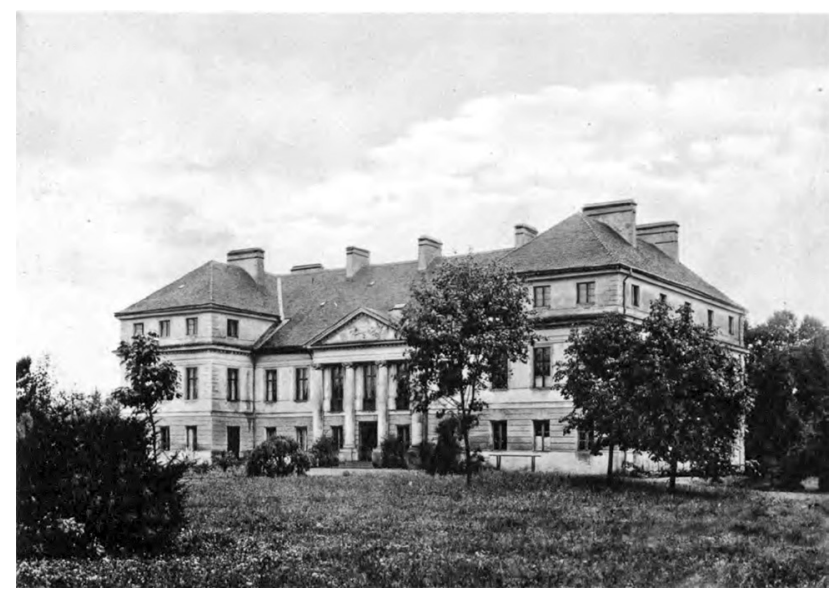

Ryc. 1a. Pałac w Siedlcu, 1912 r. (fot. L. Durczykiewicz), repr. z: „Dwory polskie w Wielkiem Księstwie Poznańskiem"

Fig. 1a. The Palace in Siedlec, 1912 (photo: L. Durczykiewicz), reproduction from: "Dwory polskie w Wielkiem Księstwie Poznańskiem"

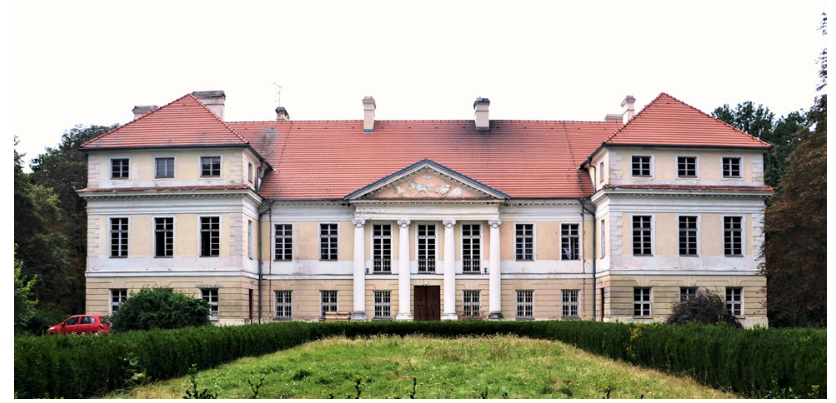

Ryc. 1b. Pałac w Siedlcu, 2018 r. (fot. W. Antkowiak) Fig. 1b. The Palace in Siedlec, 2018 (photo: W. Antkowiak) 


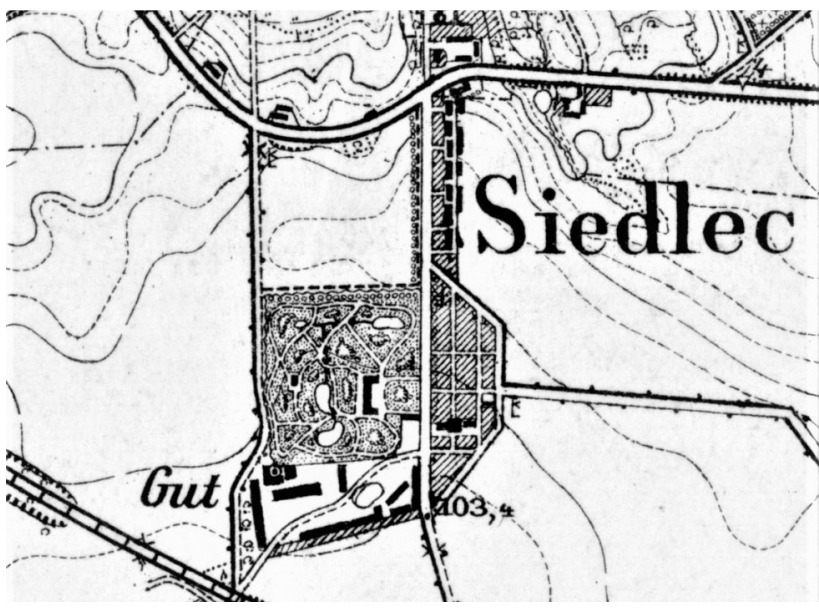

Ryc. 2. Siedlec na mapie z 1889 roku; 1:25 000

Fig. 2. Siedlec on the map from 1889; 1:25 000

pod koniec XVIII wieku park, prawdopodobnie w stylu ogrodu barokowo-klasycystycznego.

W 1803 roku zmarł Onufry Krzycki, a w 1814 roku kolejny bezdzietny właściciel - Józef Krzycki, brat Onufrego. W 1825 roku majątek zakupił Józef Grabowski herbu Oksza z Grylewa, po którym odziedziczyła go córka, Izabela z Grabowskich hr. Tyszkiewiczowa. W ich czasach przypuszczalnie zaprojektowano rozległe, malownicze, krajobrazowe założenie parkowe, które zajęło miejsce dawnego ogrodu oraz honorowego dziedzińca od frontu. Ten stan przedstawia mapa z 1889 roku (ryc. 2, dla porównania współczesna ortofotomapa - ryc. 3); dawny, położony na

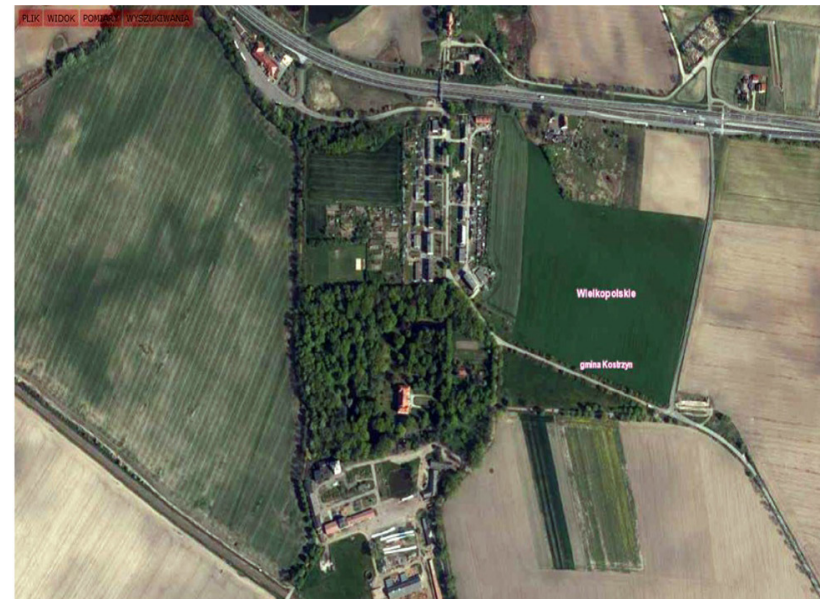

Ryc. 3. Mapa współczesna (https://www.google.pl/maps/; 2018 r.)

Fig. 3. Siedlec on a contemporary map (https://www.google.pl/maps/; 2018)

wschód od dziedzińca pałacowego mniejszy fragment kompozycji ogrodowej wyłączono z parku właściwego, nadając mu użytkowy charakter. Dziedziniec pałacowy uległ zasadniczym przekształceniom - zredukowano oficyny, a w centrum utworzono obszerny gazon. Przebieg dróg i alejek parkowych gruntownie zmieniono - $z$ układu regularnego w swobodny, w dużym stopniu zachowany do dzisiaj.

W drugiej połowie XIX wieku Siedlec należał do hrabiów Potulickich, a w XX stuleciu do Mielżyńskich - majątek kupiła Konstancja Mielżyńska z Iwna, po

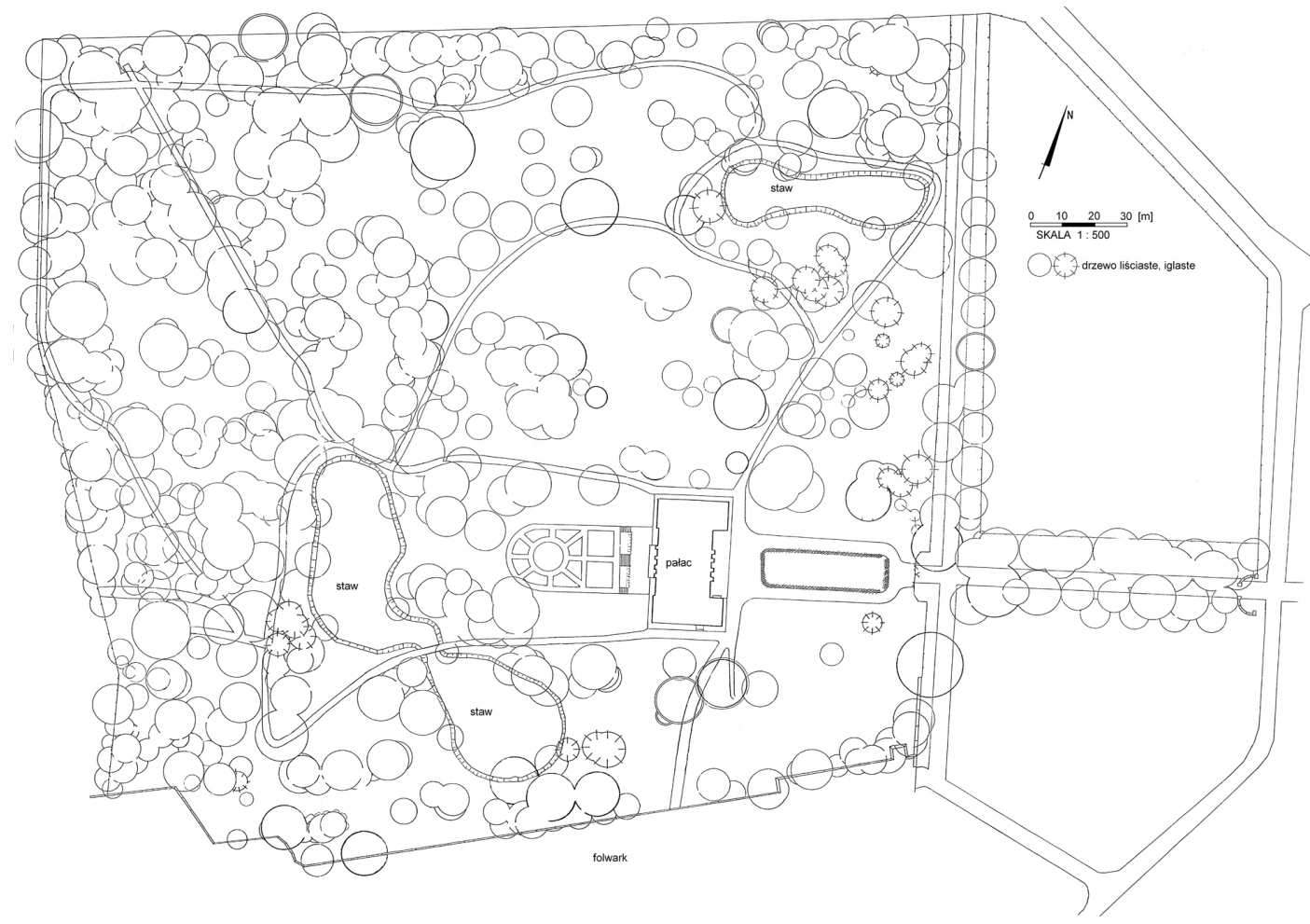

Ryc. 4. Plan parku (wg WiLANOwsKIEGo 1998, zmodyfikowane)

Fig. 4. A plan of the park (according to Wilanowski 1998, modified) 


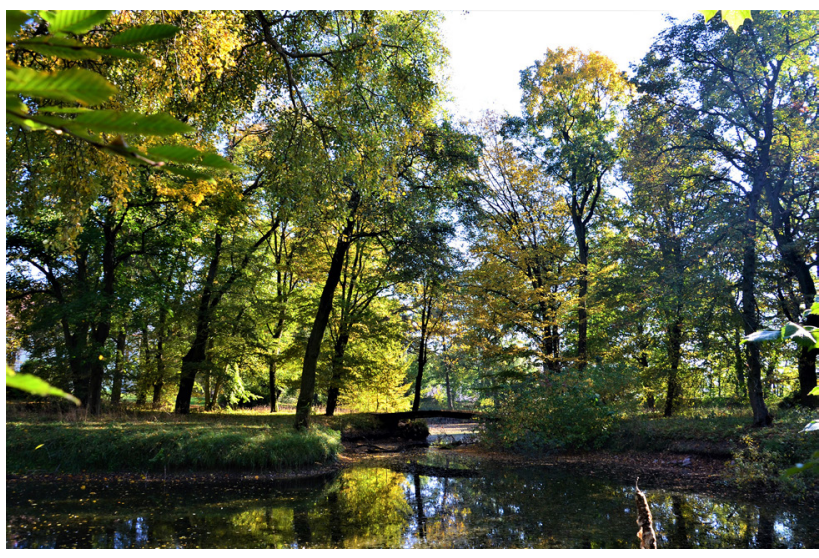

Ryc. 5. Fragment parku z jednym ze stawów (fot. W. Antkowiak)

Fig. 5. A fragment of the park with one of the ponds (photo: W. Antkowiak)

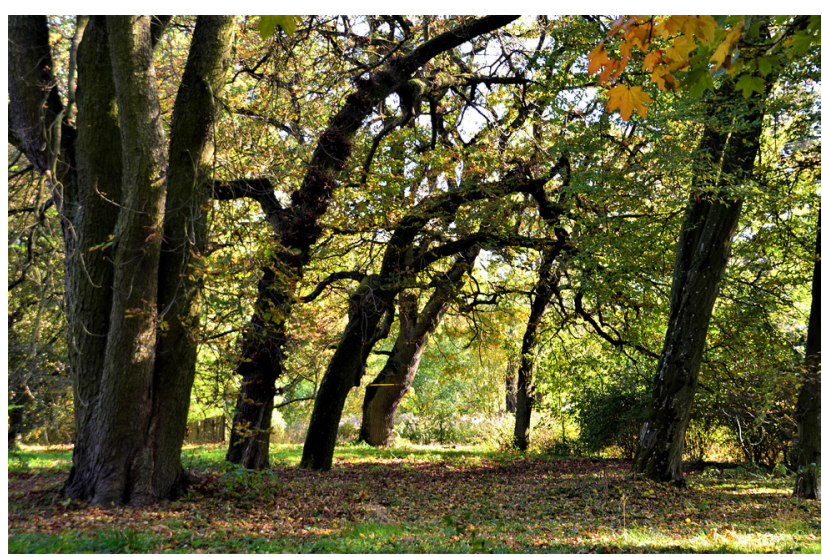

Ryc. 7. Grupa kasztanowców w pobliżu południowo-zachodniej ściany pałacu (fot. W. Antkowiak)

Fig. 7. A group of horse chestnuts near the south-western wall of the palace (photo: W. Antkowiak)

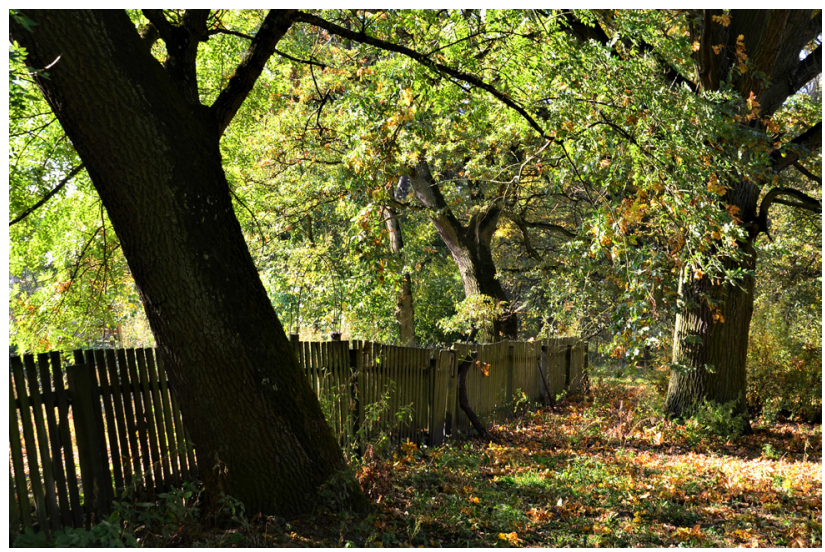

Ryc. 9. Jesion i dęby przy południowej granicy parku (fot. W. Antkowiak)

Fig. 9. Ash and oak trees at the southern border of the park (photo: W. Antkowiak)

czym sprzedała go szwagrowi Ignacemu Mielżyńskiemu, który był jego właścicielem do końca II wojny światowej. Po wojnie majątek został przejęty przez Skarb Państwa i był użytkowany przez Państwową

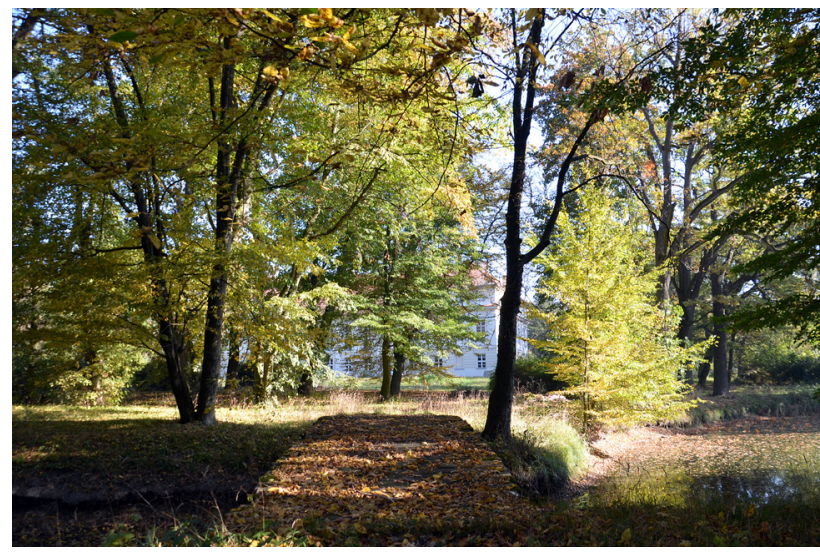

Ryc. 6. Mostek na stawie prowadzący do pałacu (fot. W. Antkowiak)

Fig. 6. Bridge on the pond leading to the palace (photo: W. Antkowiak)

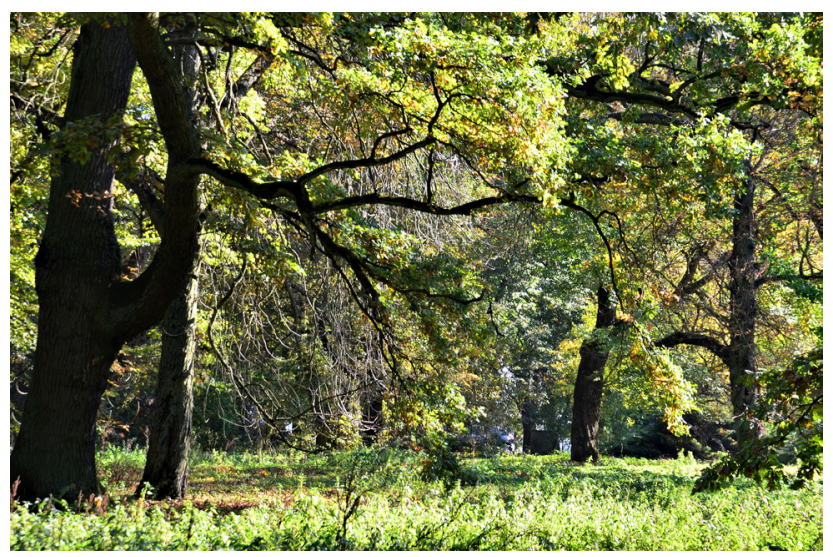

Ryc. 8. Okazałe dęby i kasztanowce w centralnej części parku (fot. W. Antkowiak)

Fig. 8. Spectacular oaks and horse chestnuts in the central part of the park (photo: W. Antkowiak)

Stadninę Koni w Iwnie. W 1960 roku umieszczono w nim Magazyn Międzybiblioteczny Wojewódzkiej Biblioteki w Poznaniu.

Park „właściwy”, który zajmuje powierzchnię 6,36 ha, w tym wody 0,29 ha, jest obecnie własnością prywatną. W skład pierwotnego założenia pałacowego wchodziły jeszcze działki o powierzchni 1,73 ha, użytkowane przez Stadninę Koni „Iwno” Sp. z o.o., i aleje parkowe o powierzchni 0,041 ha. Plan parku przedstawiono na rycinie 4, a charakter założenia parkowego, jego malowniczość i stan dendroflory na rycinach 5-9.

\section{WYNIKI}

W 2018 roku w parku rosło 85 gatunków i odmian drzew i krzewów. Należały one do 29 rodzin botanicznych. Nagozalążkowe były reprezentowane przez cztery rodziny: miłorząbowate Ginkgoaceae, cisowate Taxaceae, sosnowate Pinaceae i cypryśnikowate Taxodiaceae, liczące 17 taksonów. Wśród 25 rodzin okrytozalążkowych stosunkowo najliczniejsze były różowate Rosaceae z 14 taksonami i klonowate 
Acearaceae z pięcioma taksonami. Skład dendroflory parku siedleckiego, w porównaniu z parkami wiejskimi, jest dość bogaty. Spośród nagozalażkowych na wymienienie zasługują: jodła kaukaska Abies nordmanniana (Steven) Spach, cyprysik Lawsona Chamaecyparis lawsoniana 'Argentea', miłorząb dwuklapowy Ginkgo biloba L. i sosna czarna Pinus nigra J.F. Arnold w liczbie 21 okazów.

Wśród okrytozalążkowych ilościowo dominuje klon polny Acer campestre L. Pnie najgrubszych okazów osiągają obwody do $290 \mathrm{~cm}$, są one regularnie walcowate, pofalowane i z guzowatymi wyroślami. Różnią się wielkością liści. Wydały odrośla pniowe i odrosty korzeniowe. Owocują obficie i odnawiają się spontanicznie z samosiewu. Ta populacja klonu polnego zasługuje na szczegółowe badania biometryczne. Dość liczny jest także udział klonu pospolitego Acer platanoides L. i klonu jaworu A. pseudoplatanus L. W parku rosną także dwa drzewa klonu pospolitego odmiany Schwedlera A. platanoides 'Schwedleri', obecnie rzadko spotykanego. Znaczne wymiary osiągają drzewa kasztanowca zwyczajnego Aesculus hippocastanum L. Dużymi drzewami są topole szare Populus canescens (Aiton) Sm. (7 okazów), o obwodach przekraczających $300 \mathrm{~cm}$ i wysokości do $30 \mathrm{~m}$. W czasie kwitnienia w maju-czerwcu szczególnie ozdobna jest wielka grupa kolkwicji chińskiej Kolkwitzia amabilis Graebn. Jesienią purpurą liści mienią się wielkie, rozrośnięte pnącza winobluszczu pięciolistkowego Parthenocissus quinquefolia (L.) Planch.

Zamieszczony wykaz drzew i krzewów opracowano w układzie alfabetycznym, bardziej przejrzystym od systematycznego.

\section{WYKAZ GATUNKÓW ORAZ ODMIAN DRZEW I KRZEWÓW UPRAWIANYCH W PARKU W SIEDLCU}

\section{NAGOZALAZŻKOWE - GYMNOSPERMAE}

Abies nordmanniana (Steven) Spach - jodła kaukaska - jedno młode drzewo o wysokości $8 \mathrm{~m}$, we wschodniej części parku.

Chamaecyparis lawsoniana (A. Murray) Parl. - cyprysik Lawsona - dwa młode drzewa o wysokości $6 \mathrm{~m}$, we wschodniej części parku.

Chamaecyparis lawsoniana 'Argentea' - cyprysik Lawsona odmiana srebrzysta - jedno młode drzewo nad stawem z kładką.

Ginkgo biloba L. - miłorzą b dwuklapowy - dwa drzewa; starsze, żeńskie ma obwód $287 \mathrm{~cm}$, pień w dolnej
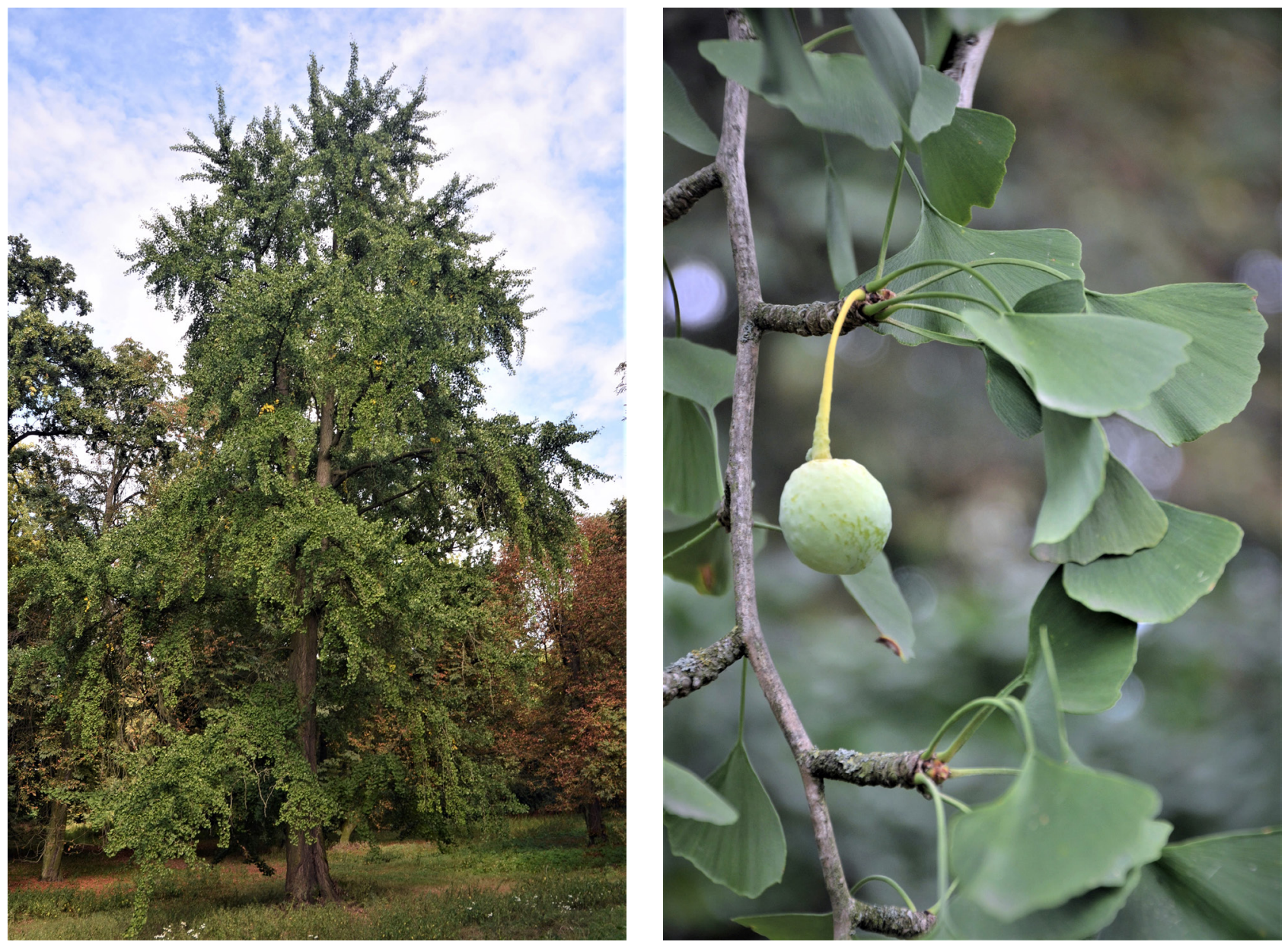

Ryc. 10. Żeński okaz miłorzębu dwuklapowego o obwodzie pnia $287 \mathrm{~cm}$ (fot. W. Antkowiak)

Fig. 10. Female specimen of maidenhair tree with a trunk circumference of $287 \mathrm{~cm}$ (photo: W. Antkowiak) 
części pofalowany, na wysokości 9 m rozwidlony na trzy konary, obradza nasiona. W odziomku z pąków śpiących rozwinęły się pojedyncze liście. Pod jedną najniższą gałęzią boczną znajdują się zaczątki tzw. czi-czi. Piękne, gęsto ulistnione, zdrowe drzewo (ryc. 10). Drugie drzewo - młode - ma obwód $51 \mathrm{~cm}$ i wysokość $11 \mathrm{~m}$.

Juniperus chinensis L. - jałowiec chiński - kilka krzewów w różnych częściach parku.

Juniperus $\times$ pfitzeriana (L. Späth) P.A. Schmidt - jałowiec Pfitzera - okazałe, rozrośnięte krzewy w różnych częściach parku.

Larix decidua Mill. - modrzew europejski - kilka drzew, największe o obwodzie $152 \mathrm{~cm}$ i wysokości $25 \mathrm{~m}$.

Picea abies (L.) H. Karst. - świerk pospolity - kilka okazów, najgrubsze o obwodzie 169 i $165 \mathrm{~cm}$.

Picea pungens Engelm. - świerk kłujący - jeden okaz za bramą wjazdową do parku.

Picea pungens 'Glauca' - świerk kłujący odmiana sina cztery młode okazy, za bramą wjazdową do parku.

Pinus nigra J.F. Arnold - sosna czarna - 21 okazów o obwodach od 11 do $227 \mathrm{~cm}$, w różnych częściach parku. W dolnej części strzał 19 drzew blizna o różnej powierzchni po odartej korowinie. Blizny mają znaczną powierzchnię i drzewa nie będą w stanie ich zagoić. Najliczniejszy gatunek wśród roślin nagozalążkowych.

Platycladus orientalis (L.) Franco - biota wschodnia młody wielopędowy okaz o wysokości $2,5 \mathrm{~m}$.

Pseudotsuga menziesii (Mirb.) Franco - daglezja zielona - siedem okazów o obwodach 68-117 cm.

Taxus baccata L. - cis pospolity - jeden okaz żeński, szeroki, zdrowy, w środkowej części parku.

Thuja occidentalis L. - żywotnik zachodni - jeden okaz o wysokości $9 \mathrm{~m}$, za pałacem.

Thuja occidentalis 'Globosa' - żywotnik zachodni odmiana kulista - kilka dużych okazów za pałacem.

Thuja plicata Donn ex D. Don - żywotnik olbrzymi jeden młody okaz.

\section{OKRYTOZALĄŻKOWE - ANGIOSPERMAE}

Acer campestre L. - klon polny - bardzo liczne okazy w całym parku. Największe mają obwody przekraczające $200 \mathrm{~cm}$, np. 290, 289, 264, 263, 248, 229, $228,225,224,222,215,206$ i $200 \mathrm{~cm}$. Okaz o obwodzie $289 \mathrm{~cm}$ na pofalowanym pniu ma duże guzowate wyrośla. Okaz o obwodzie $248 \mathrm{~cm}$ rozwinął pędy odroślowe z szyi korzeniowej. Niektóre okazy są zrośnięte nasadami pni i korzeniami, a w pniach mają małe dziuple. Klon ten owocuje obficie i odnawia się spontanicznie $z$ samosiewu. Drzewa rozwinęły szerokie, gęsto ulistnione korony.

Acer negundo 'Variegatum' - klon jesionolistny odmiana białopstra - jeden okaz o liściach biało obrzeżonych, o obwodzie $51 \mathrm{~cm}$ i wysokości $9 \mathrm{~m}$.
Acer platanoides L. - klon pospolity - dość liczne okazy w różnych częściach parku. Najgrubsze o obwodach: 280, 263, 262, 261, 254, 237, 234, 227 i 220 $\mathrm{cm}$. Okaz o obwodzie $212 \mathrm{~cm}$ wytworzył wyraźne przypory korzeniowe. Oryginalnie wygląda okaz o pięciu pniach zrośniętych $\mathrm{w}$ odziomku.

Acer platanoides 'Schwedleri' - klon pospolity odmiana Schwedlera - dwa okazy o obwodach 262 i 186 $\mathrm{cm}$, gęsto ulistnione.

Acer pseudoplatanus L. - klon jawor - kilkanaście okazów, najgrubsze o obwodach: 243, 240, 235, 227, $215,193,170$ i $165 \mathrm{~cm}$. Okaz o obwodzie $240 \mathrm{~cm}$ rozwinął odrosty korzeniowe, co wcześniej u tego gatunku nie było znane.

Aesculus hippocastanum L. - kasztanowiec zwyczajny - kilkanaście okazów, najgrubsze o obwodach: 293, 257, 251, 236, 231, 224 i $211 \mathrm{~cm}$. Wszystkie w mniejszym lub większym stopniu uszkodzone przez szrotówka kasztanowcowiaczka Cameraria ohridella. Larwy szkodnika zjadają miękisz asymilacyjny liści, co prowadzi do powstania tzw. min. Zmniejsza się wydajność fotosyntetyczna drzew, prowadząca do ich osłabienia biologicznego. Pień największego okazu na wysokości $70 \mathrm{~cm}$ ma obwód $417 \mathrm{~cm}$, wyżej jest rozwidlony na trzy konary - pnie!

Berberis verruculosa Hemsl. \& E.H. Wilson - berberys gruczołkowaty - jeden okazały krzew.

Berberis vulgaris L. - berberys pospolity - jeden gęsty krzew.

Berberis vulgaris 'Atropurpurea' - berberys pospolity kilka rozrośniętych krzewów.

Betula pendula Roth - brzoza brodawkowata - kilka okazów, najgrubszy o obwodzie $132 \mathrm{~cm}$.

Betula pendula 'Youngii' - brzoza brodawkowata odmiana Younga - jeden mały okaz.

Buxus sempervirens L. - bukszpan wieczniezielony pod ałyczą koło ogrodu owocowego.

Buxus sempervirens 'Suffruticosa' - bukszpan wieczniezielony odmiana karłowa - w obwódce kompozycyjnej przed frontem pałacu.

Caragana arborescens Lam. - karagana syberyjska - wysokie krzewy po obydwóch stronach bramy wjazdowej do ogrodzonej części parku.

Carpinus betulus L. - grab zwyczajny - kilkanaście okazów w różnych częściach parku. Najgrubsze o pojedynczym pniu mają obwody: $206 \mathrm{~cm}$ (pień z kieszeniowatymi zagłębieniami), $193 \mathrm{~cm}, 185$ $\mathrm{cm}, 2 \times 184 \mathrm{~cm}, 155,148$ i $125 \mathrm{~cm}$. Okaz zrośnięty $z$ dwóch pni ma łączny obwód $256 \mathrm{~cm}$.

Chaenomeles Xsuperba (Frahm) Rehder - pigwowiec pośredni - jeden szeroki krzew.

Cornus alba L. - dereń biały - wielka grupa starych krzewów za pałacem.

Cornus sanguinea L. - dereń świdwa - pojedyncze krzewy w różnych częściach parku; wydają odrosty.

Cotinus coggygria Scop. - perukowiec podolski - jeden wysoki krzew koło stawu z kładką. 
Clematis vitalba L. - powojnik pnący - wspina się na berberysie pospolitym.

Corylus avellana L. - leszczyna pospolita - pojedyncze krzewy w kilku miejscach.

Cotoneaster dielsianus E. Pritz. - irga Dielsa - pojedyncze, zdrowe krzewy.

Cotoneaster divaricatus Herder et E.H. Wilson - irga rozkrzewiona - gęsty krzew do wysokości 2,5 m.

Cotoneaster horizontalis Decne. - irga pozioma w dwóch miejscach.

Deutzia scabra Thunb. - żylistek szorstki - dwa duże krzewy przy ogrodzeniu po stronie wschodniej.

Euonymus europaeus L. - trzmielina zwyczajna - kilka niewielkich krzewów w różnych częściach parku. Okaz drzewkowaty wysokości $3,5 \mathrm{~m}$, na wysokości $70 \mathrm{~cm}$ ma pęd o obwodzie $26 \mathrm{~cm}$.

Fagus sylvatica L. - buk zwyczajny - kilka okazów w różnych miejscach parku.

Fagus sylvatica 'Pendula' - buk zwyczajny odmiana zwisająca - jeden okaz o obwodzie $191 \mathrm{~cm}$ i gęstej koronie, ale jednostronnej z powodu zacienienia bocznego przez drzewa sąsiednie (ryc. 11).

Forsythia $\times$ intermedia Zabel - forsycja pośrednia - rośnie pojedynczo i $\mathrm{w}$ grupach.

Fraxinus excelsior L. - jesion wyniosły - kilka okazów w różnych częściach parku, najgrubsze o obwodach: 290, 254, 246 i 225 cm, i wysokości około $25 \mathrm{~m}$.
Hydrangea macrophylla (Thunb. ex Murray) Ser. - hortensja ogrodowa - rośnie na klombie obramowanym przez bukszpan wieczniezielony, po północnej stronie pałacu.

Juglans regia L. - orzech włoski - dwa okazy, stary ma obwód $175 \mathrm{~cm}$, rośnie ukośnie, owocuje, zdrowy (ryc. 12), drugi to okaz młody.

Kolkwitzia amabilis Graebn. - kolkwicja chińska - trzydzieści krzewów o wysokości 3 m rośnie blisko siebie, tworząc grupę $8 \times 4 \mathrm{~m}$, przy drodze prowadzącej do pałacu. W czasie kwitnienia wygląda imponująco (ryc. 13).

Ligustrum vulgare L. - ligustr pospolity - nieliczne niewielkie krzewy w różnych częściach parku.

Lonicera xylosteum L. - suchodrzew pospolity - dość liczny w różnych częściach parku. Znosi stanowiska o głębokim cieniu.

Magnolia Xsoulangiana Soul.-Bod. - magnolia pośrednia - jeden kilkupędowy krzew o wysokości około $3 \mathrm{~m}$, nad stawem $\mathrm{z}$ kładką.

Mahonia aquifolium (Pursh) Nutt. - mahonia pospolita - kilkanaście starych krzewów.

Malus domestica Borkh. - jabłoń domowa (odmiany uprawne) - w dawnym ogrodzie owocowym.

Malus × purpurea (E. Barbier et al.) Rehder - jabłoń purpurowa - jeden okaz przy ogrodzeniu we wschodniej części parku.

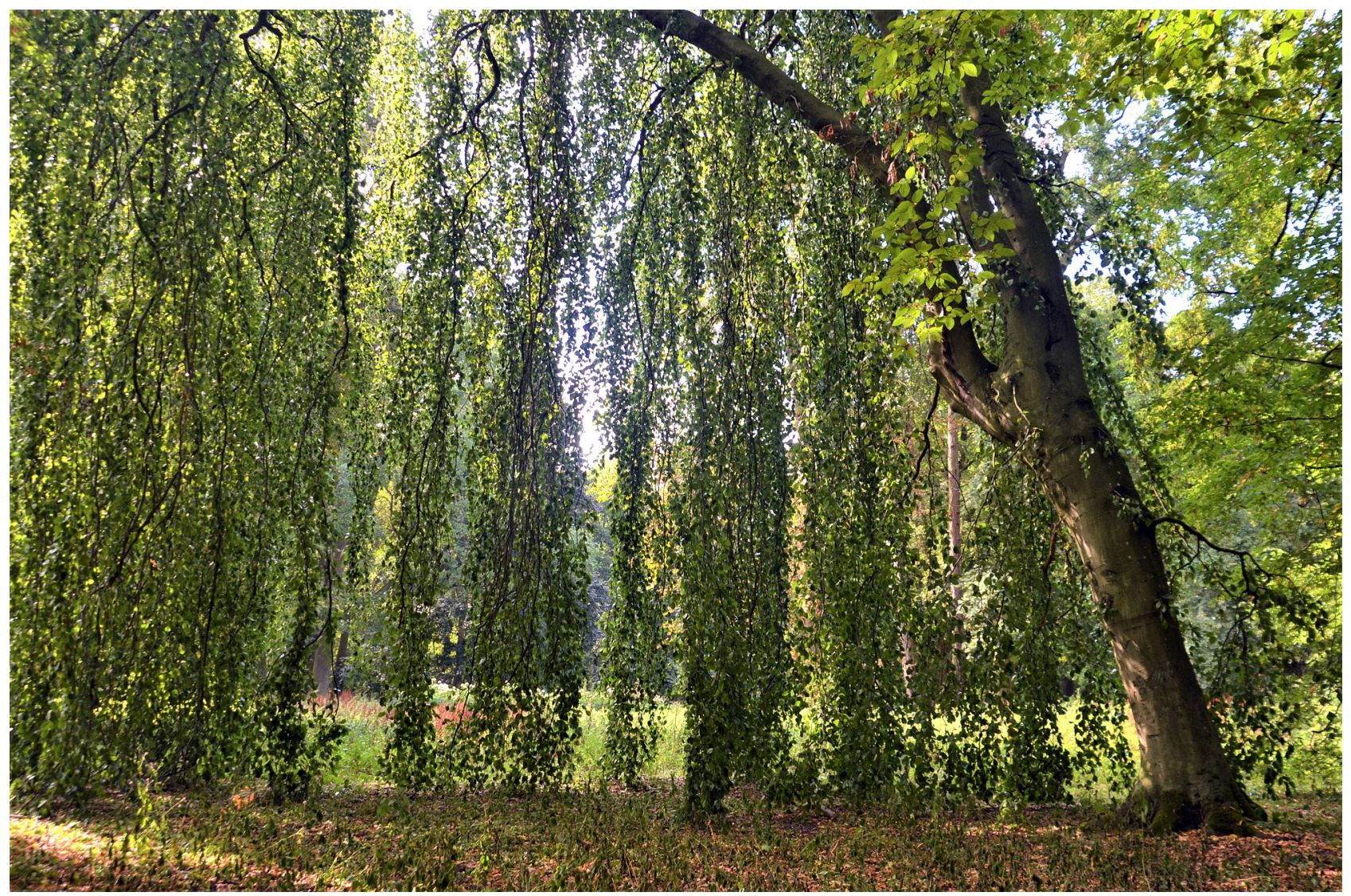

Ryc. 11. Fagus sylvatica 'Pendula' o obwodzie $191 \mathrm{~cm}$ (fot. W. Antkowiak)

Fig. 11. Fagus sylvatica 'Pendula' with a circumference of $191 \mathrm{~cm}$ (photo: W. Antkowiak) 


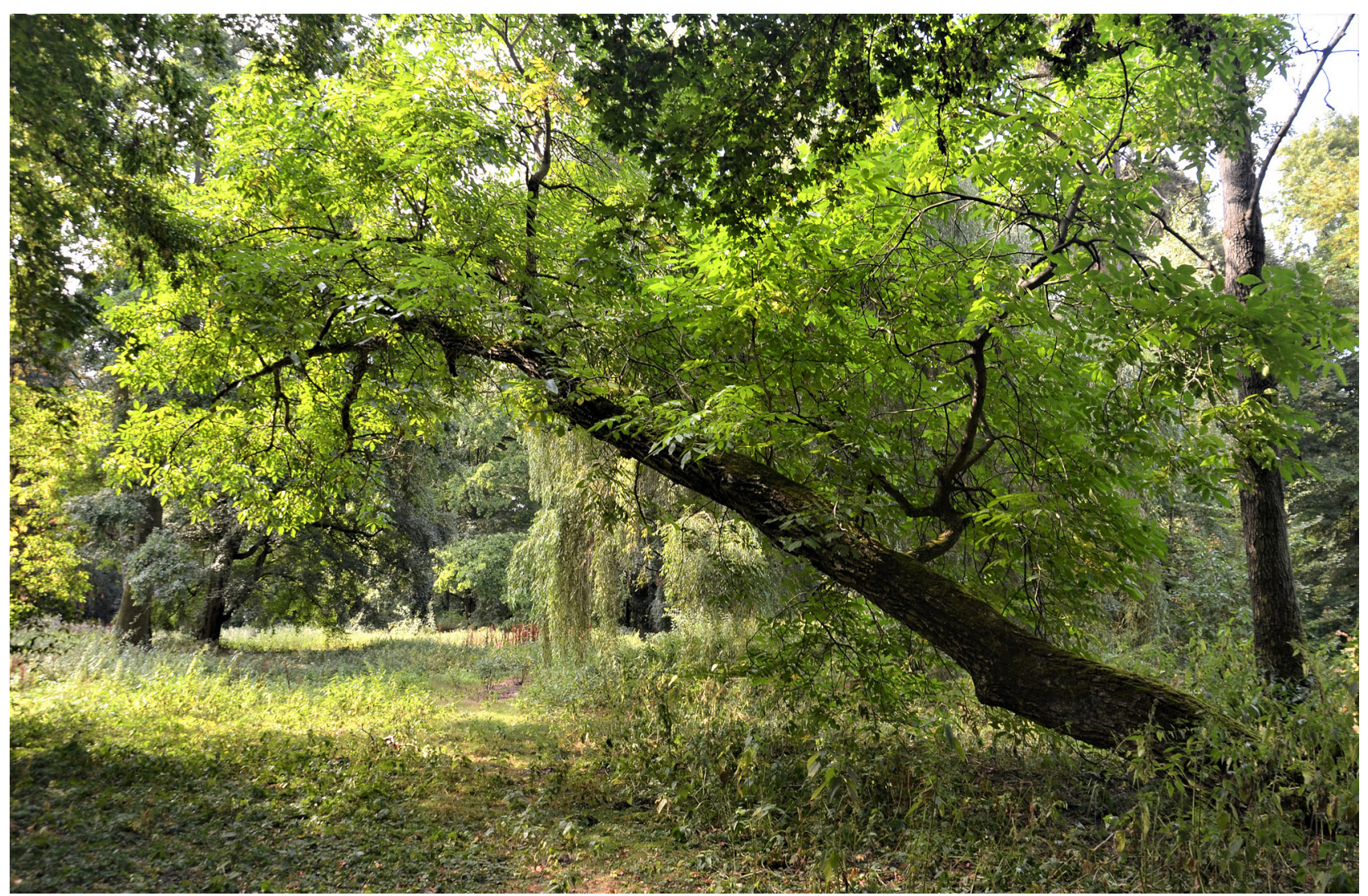

Ryc. 12. Ukośnie rosnący orzech włoski o obwodzie $175 \mathrm{~cm}$ (fot. W. Antkowiak)

Fig. 12. An obliquely growing common walnut with a circumference of $175 \mathrm{~cm}$ (photo: W. Antkowiak)

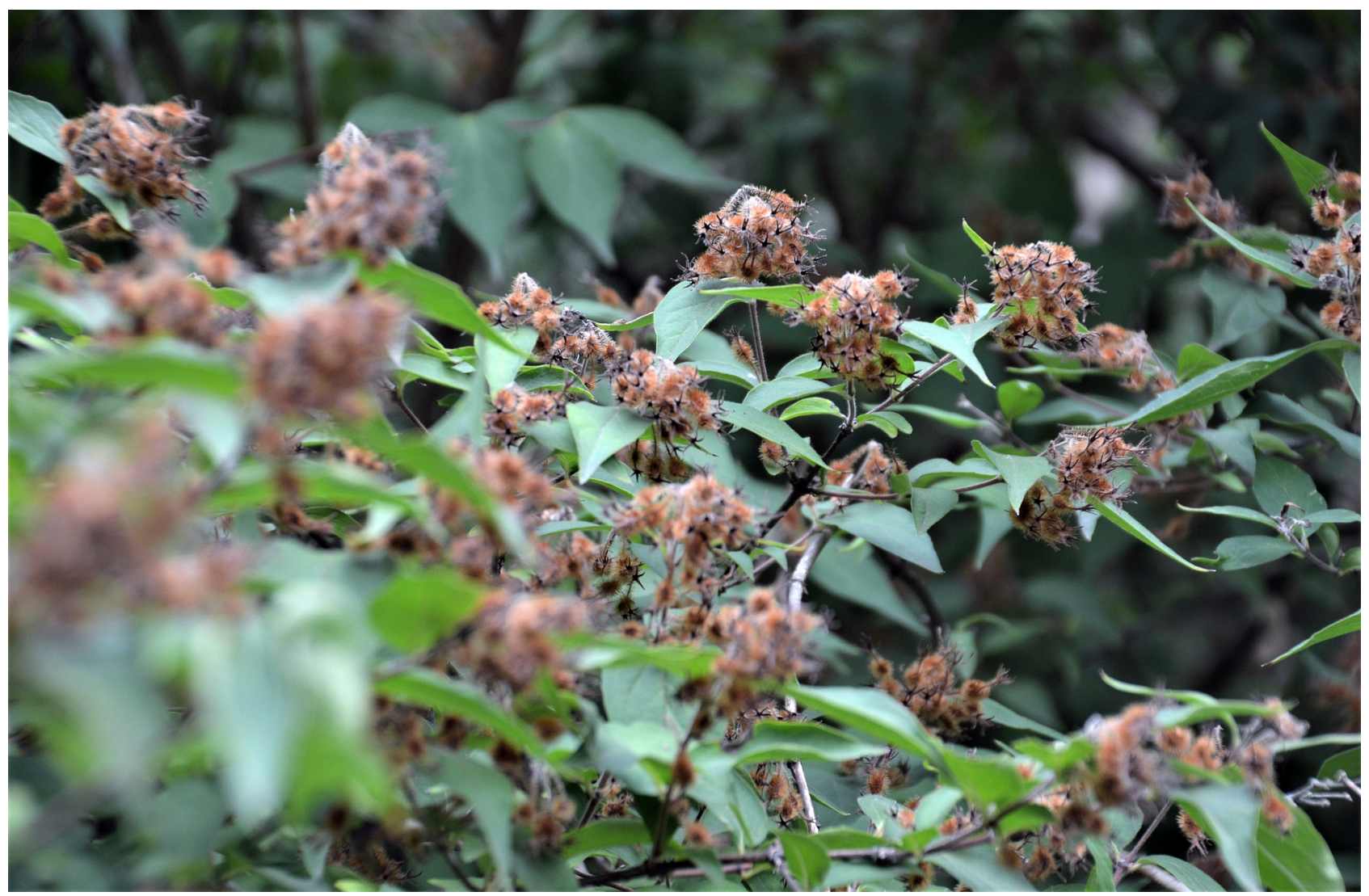

Ryc. 13. Owocująca kolkwicja chińska (fot. W. Antkowiak)

Fig. 13. Fruiting beauty bush Kolkwitzia amabilis (photo: W. Antkowiak) 
Parthenocissus quinquefolia (L.) Planch. - winobluszcz pięciolistkowy - wielkie rozrośnięte pnącze wspinające się na uschniętym dębie szypułkowym odmiany stożkowatej i na żywym drzewie tej odmiany oraz na glebie w sąsiedztwie tych drzew, po stronie północnego szczytu pałacu.

Philadelphus coronarius L. - jaśminowiec wonny - okazałe krzewy w grupach w kilku częściach parku, o wysokości ponad $3 \mathrm{~m}$.

Philadelphus coronarius - hybridus - forma mieszańcowa - krzewy o mniejszych liściach niż u gatunku poprzedniego, rosną także słabiej; w południowej części parku.

Populus $\times$ canescens (Aiton) Sm. - topola szara - siedem okazów, najgrubsze o obwodach: 303, 277, 200 oraz $180 \mathrm{~cm}$ i wysokości do $30 \mathrm{~m}$, w północnej części parku, blisko ogrodzenia.

Prunus cerasifera Ehrh. - śliwa wiśniowa (ałycza) - formy drzewiaste i krzewiaste $\mathrm{w}$ różnych częściach parku. Najgrubszy okaz ma pień o obwodzie 107 $\mathrm{cm}$. Obradzają dojrzałe owoce żółte i czerwone oraz odnawiają się samosiewnie.

Prunus cerasifera 'Pissardii' - śliwa wiśniowa odmiana Pissarda - jeden okaz o wysokości $4 \mathrm{~m}$, we wschodniej części parku blisko ogrodzenia.

Prunus domestica L. - śliwa domowa - stara odmiana o małych, kulistych, ciemnych, smacznych owocach.
Quercus robur L. - dąb szypułkowy - liczne okazy, najgrubszy ma pień o obwodzie $517 \mathrm{~cm}$, na wysokości $170 \mathrm{~cm}$ rozwidlony na dwa potężne konary (ryc. 14). Inne okazałe mają obwody: $2 \times 348$, 343, 333, 327, 315, 294 i 275 cm. Wysokość największych przekracza trzydzieści metrów.

Quercus robur 'Fastigiata' - dąb szypułkowy odmiana stożkowata - okaz o obwodzie $201 \mathrm{~cm}$ ma średnio zwartą koronę. Drugi ma koronę bardzo gęsto oplecioną winobluszczem pięciolistkowym. Trzeci okaz został „zaduszony” przez winobluszcz.

Rhamnus cathartica L. - szakłak pospolity - jeden krzew z pędami o obwodach 51 i $42 \mathrm{~cm}$ oraz wysokości $7 \mathrm{~m}$, w południowej części parku.

Ribes alpinum L. - porzeczka alpejska - nielicznie w kilku miejscach parku.

Robinia pseudoacacia L. - robinia akacjowa - kilka okazów, najgrubszy o obwodzie 208 cm i wysokości $25 \mathrm{~m}$.

Salix alba L. - wierzba biała - usychający okaz, nad stawem w południowej części parku.

Salix fragilis L. - wierzba krucha - po okazie trójpniowym został jeden pień usychający.

Salix × sepulcralis 'Chrysocoma' - wierzba płacząca okaz o obwodzie $183 \mathrm{~cm}$ rośnie pochyło nad stawem.

Sambucus nigra L. - bez czarny - w różnych miejscach parku.

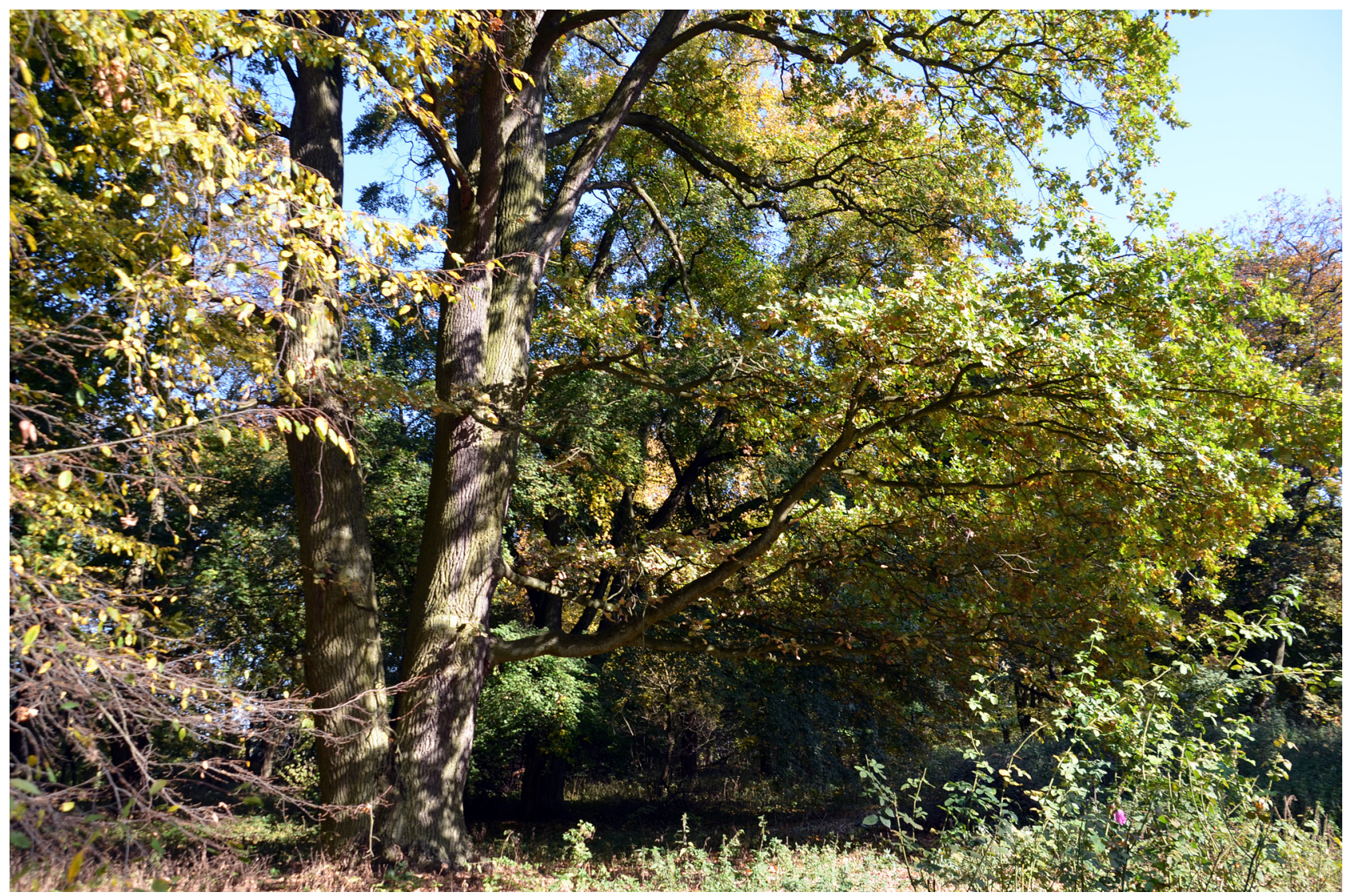

Ryc. 14. Najgrubszy w parku dąb szypułkowy o obwodzie $517 \mathrm{~cm}$ (fot. W. Antkowiak)

Fig. 14. The thickest in the park pedunculate oak with a circumference of $517 \mathrm{~cm}$ (photo: W. Antkowiak) 
Sorbus aucuparia L. - jarząb pospolity - niewielkie drzewa w dwóch miejscach.

Sorbus hybrida L. - jarząb pośredni - z szyi korzeniowej pniaka po ściętym drzewie wyrosły liczne pędy odroślowe, po południowej stronie parku.

Spiraea chamaedryfolia L. em. Jacq. - tawuła ożankolistna - jedna grupa.

Spiraea japonica L. f. - tawuła japońska - dwie grupy.

Spiraea $\times$ vanhouttei (Briot) Zabel - tawuła van Houtte'a - dwie grupy.

Syringa vulgaris L. - lilak pospolity - dwa krzewy o wysokości około $3 \mathrm{~m}$, we wschodniej części przed ogrodzeniem.

Symphoricarpos albus (L.) S.F. Blake - śnieguliczka biała - grupy w kilku miejscach.

Tilia cordata Mill. - lipa drobnolistna - kilka okazów, najgrubszy o obwodzie $278 \mathrm{~cm}$, pień prosty, dziupla w jego odziomku.

Tilia platyphyllos Scop. - lipa szerokolistna - kilka okazów, najładniejszy o obwodzie $190 \mathrm{~cm}$, bardzo gęsto ugałęziony, gałęziami dotykający gleby.

Ulmus laevis Pall. - wiąz szypułkowy - kilkanaście okazów w różnych częściach parku, najgrubsze o obwodach $340 \mathrm{~cm}, 2 \times 280 \mathrm{~cm}$ i $265 \mathrm{~cm}$, z wydatnymi przyporami korzeniowymi.

Ulmus minor Mill. - wiąz polny - kilkanaście młodych okazów w różnych częściach parku.

Viburnum lantana L. - kalina hordowina - jeden duży krzew bez owoców.

Viburnum opulus L. - kalina koralowa - kilka niewielkich krzewów w różnych miejscach.

\section{DRZEWA ZASŁUGUJĄCE NA MIANO POMNIKÓW PRZYRODY}

Rozporządzenie Ministra Środowiska z dnia 4 grudnia 2017 r. (RozPoRZĄDZENIE... 2017) w sprawie kryteriów uznawania tworów przyrody żywej i nieożywionej za pomniki przyrody wskazuje dwa kryteria jako podstawę objęcia drzewa ochroną pomnikową: 1) obwód pnia drzewa mierzonego na wysokości 130 cm dla poszczególnych rodzajów i gatunków drzew oraz, lub 2) wyróżnianie się wśród innych drzew tego samego rodzaju lub gatunku w skali kraju, województwa lub gminy, ze względu na obwód pnia, wysokość, szerokość korony, wiek, występowanie w skupiskach, w tym w alejach lub szpalerach, pokrój lub inne cechy morfologiczne, a także inne wyjątkowe walory przyrodnicze, naukowe, kulturowe, historyczne lub krajobrazowe. Pośród drzew parku na miano drzewa pomnikowego zasługują:

Ginkgo biloba L. - miłorząb dwuklapowy - drzewo o obwodzie pnia $287 \mathrm{~cm}$ (wymagany obwód min. $150 \mathrm{~cm}$ ),

Acer campestre L. - klon polny - drzewa o obwodach: 290, 289, 264, 263, 248, 229, 228, 225, 224, 222, 215,206 i $200 \mathrm{~cm}$,
Acer platanoides L. - klon pospolity - drzewa o obwodach 280, 263, 262 i $261 \mathrm{~cm}$,

Acer platanoides 'Schwedleri' - klon pospolity odmiana Schwedlera - okaz o obwodzie $262 \mathrm{~cm}$,

Aesculus hippocastanum L. - kasztanowiec zwyczajny - drzewa najgrubsze o obwodach: 293, 257 i 251 cm. Pień największego okazu na wysokości $70 \mathrm{~cm}$ ma obwód $417 \mathrm{~cm}$, wyżej jest rozwidlony na trzy konary - pnie,

Carpinus betulus L. - grab zwyczajny - jeden okaz o obwodzie $206 \mathrm{~cm}$,

Fraxinus excelsior L. - jesion wyniosły - dwa najgrubsze okazy o obwodach 290 i $254 \mathrm{~cm}$,

Quercus robur L. - dąb szypułkowy - liczne okazy, najgrubsze o obwodzie pnia $517 \mathrm{~cm}, 2 \times 348,343$, 333, 327 i $315 \mathrm{~cm}$,

Ulmus laevis Pall. - wiąz szypułkowy - okazy o obwodach $340,2 \times 280$ i $265 \mathrm{~cm}$.

Ochroną pomnikową warto byłoby objąć kasztanowca o obwodzie pnia $315 \mathrm{~cm}$, który rośnie obok bramy prowadzącej do parku właściwego.

\section{ZMIANA W SKŁADZIE DENDROFLORY PARKU PO 20 LATACH}

W 2018 roku w porównaniu z inwentaryzacją wykonaną w 1998 roku, czyli po 20 latach, w parku nie stwierdzono następujących taksonów: Acer saccharinum (klon srebrzysty), A. tatarica subsp. ginnala (klon tatarski podgatunek ginnala), Berberis koreana (berberys koreański), B. thunbergii 'Atropurpurea' (berberys Thunberga odmiana purpurowa), Betula pubescens (brzoza omszona), Cornus controversa (dereń pagodowy), Cotoneaster bullata (irga pomarszczona), Hamamelis japonica (oczar japoński), H. mollis (oczar omszony), Philadelphus pubescens (jaśminowiec omszony), Physocarpus opulifolius (pęcherznica kalinolistna), Populus alba (topola biała), P. ×canadensis (topola kanadyjska), P. tremula (topola osika), Pyracantha coccinea (ognik szkarłatny), Pyrus communis (grusza pospolita), Ribes americanum (porzeczka amerykańska), R. sanguinea (porzeczka krwista), Sorbus intermedia (jarząb szwedzki), Symphoricarpos ×chenaultii (śnieguliczka Chenaulta), Taxus media (cis pośredni), Ulmus glabra 'Camperdownii' (wiąz górski odmiana Camperdowna). Przyczyny zmian są trudne do określenia.

\section{DRZEWA I KRZEWY ZADRZEWIENIA PRZYLEGEEGO DO PARKU}

Zadrzewienie wchodziło $\mathrm{w}$ skład parku na samym początku jego powstawania. W odróżnieniu od parku właściwego nie jest ogrodzone, i jest ogólnodostępne. W zadrzewieniu wyróżnia się sześć alei zorientowanych $\mathrm{w}$ różnych kierunkach. Tworzą je lipy: drobnolistna i szerokolistna, dąb szypułkowy i jesion wyniosły. 
Drzewa i krzewy nagozalążkowe reprezentują: Abies concolor (Gordon) Lindl. ex Hildebr. - jodła jednobarwna, Juniperus chinensis L. - jałowiec chiński, J. ×pfitzeriana (Späth) P.A. Schmidt - jałowiec pośredni, J. virginiana 'Gray Owl' - jałowiec wirginijski odmiana 'Gray Owl', Larix kaempferi (Lamb.) Carrière - modrzew japoński - dwa wysokie okazy, o obwodach pni 109 i $66 \mathrm{~cm}$, Picea abies (L.) H. Karst. świerk pospolity (6 okazów, w tym 4 wysokie), Picea pungens 'Glauca' - świerk kłujący odmiana sina, Thuja occidentalis 'Columnea' - żywotnik zachodni odmiana kolumnowa.

Drzewa i krzewy okrytozalążkowe są zdecydowanie liczniejsze. Oprócz wymienionych wcześniej lip, jesionu i dębu na uwagę zasługują dwa wielkie kasztanowce zwyczajne - Aesculus hippocastanum L. Grubszy ma pień o obwodzie $355 \mathrm{~cm}$, dwa grube konary i dużą dziuplę po wyłamanym wcześniej konarze. Drugi o obwodzie $315 \mathrm{~cm}$ rośnie obok bramy prowadzącej do parku właściwego.

Zadrzewienie przyległe do parku budują także inne gatunki drzew: Prunus domestica L. - śliwa domowa, $P$. cerasifera Ehrh. - śliwa wiśniowa $=$ ałycza $\mathrm{i}$ jej odmiana Pissarda (P. cerasifera 'Pissardii'), P. cerasus L. - wiśnia pospolita, P. avium L. - czereśnia ptasia, P. persica (L.) Batsch - brzoskwinia zwyczajna, Pyrus communis L. - grusza pospolita, Malus domestica Borkh. - jabłoń domowa, Carpinus betulus L. - grab zwyczajny - pozostałość po dawnym szpalerze, Juglans regia L. orzech włoski - trzy okazy, w tym dwa stare drzewa, Salix × sepulcralis 'Chrysocoma' - wierzba płacząca i Salix alba L. - wierzba biała.

Krzewy i krzewinki okrytozalążkowe są reprezentowane przez 20 taksonów. W jednej dużej grupie występują: Syringa vulgaris L. - lilak pospolity, Symphoricarpos albus (L.) S.F. Blake - śnieguliczka biała - stare krzewy o grubych pędach pokładających się na powierzchni gleby, Viburnum opulus L. - kalina koralowa, Spiraea chamaedryfolia L. em. Jacq. - tawuła ożankolistna i Sambucus nigra L. - bez czarny. Drugą grupę tworzą stare rozrośnięte krzewy jaśminowca wonnego Philadelphus coronarius L. Innymi krzewami i krzewinkami są: Vinca minor L. - barwinek pospolity, Buxus sempervirens L. - bukszpan wieczniezielony, Forsythia Xintermedia Zabel - forsycja pośrednia - stare, duże krzewy, z guzowatymi wyroślami (tumorami) na pędach i z korzeniami przybyszowymi, wywołanymi przez bakterię Agrobacterium tumefaciens, wewnątrz, Forsythia suspensa (Thunb.) Vahl - forsycja zwisła, Cotoneaster horizontalis Decne. - irga pozioma, Yucca gloriosa L. - juka wspaniała, Weigela florida (Bunge) A. DC. - krzewuszka cudowna - jeden stary duży krzew, Corylus avellana L. - leszczyna pospolita, Ligustrum vulgare L. - ligustr pospolity, Cotinus coggygria Scop. - perukowiec podolski, Ribes nigrum L. - porzeczka czarna, $R$. spicatum Robson - porzeczka czerwona, Rosa rugosa Thunb. - róża pomarszczona, Lonicera xylosteum L. - wiciokrzew pospolity, L. tatarica L.
- wiciokrzew tatarski, Spiraea $\times$ arguta Zabel - tawuła wczesna, Spiraea $\times$ vanhouttei (Briot) Zabel - tawuła van Houtte'a i Salix integrifolia 'Alba Maculata' wierzba całolistna odmiana Alba Maculata.

\section{PODSUMOWANIE}

Park w Siedlcu jest cennym założeniem w krajobrazie rolniczym i pełni rolę biocenotyczną.

W parku rosną drzewa i krzewy należące do 85 gatunków i odmian. Dominują gatunki rodzime: klon polny, dąb szypułkowy, klon zwyczajny, klon jawor, grab zwyczajny, lipa szerokolistna, lipa drobnolistna i wiąz szypułkowy. Zdecydowana większość drzew jest zdrowa, niektóre wymagają usunięcia posuszu $z$ koron.

Na szczególną uwagę zasługuje liczna, wewnątrz zróżnicowana morfologicznie populacja klonu polnego, warta szczegółowych badań biometrycznych.

Spośród drzew obcego pochodzenia wyróżniają się: duży żeński okaz miłorzębu dwuklapowego, 21 drzew sosny czarnej i kilka kasztanowców zwyczajnych, m.in. o obwodach 293 i $257 \mathrm{~cm}$.

Znaczny udział $\mathrm{w}$ dendroflorze parku mają krzewy ozdobne, np. kolkwicja chińska, jaśminowiec wonny, bukszpan wieczniezielony, suchodrzewy i tawuły.

$\mathrm{W}$ zadrzewieniu przyległym do parku rosną 42 gatunki i odmiany drzew i krzewów. Do ciekawszych drzew należą modrzew japoński i dwa kasztanowce zwyczajne o obwodach pni 355 i $315 \mathrm{~cm}$. Zadrzewienie to $\mathrm{w}$ przyszłości może stać się integralną częścią parku.

\section{PODZIĘKOWANIE}

Państwu Odetcie i Stanisławowi Styczyńskim, właścicielom parku w Siedlcach, dziękujemy za umożliwienie wykonania niniejszego opracowania.

\section{LITERATURA}

Czekalski M. (1970): Pomnikowe drzewa w parku wiejskim w Dąbrówce pow. Poznań. Notatki Przyrodnicze 4: 6-10.

Czekalski M. (1988): Parki wiejskie i ich znaczenie dla kultury. Przegląd Wielkopolski 1: 44-47.

CzeKalski M. (1999): Park pałacowy w Konarzewie koło Poznania i zmiany w składzie jego dendroflory po 182 latach. Rocznik Dendrologiczny 47: 97-122.

CzeKalski M. (2000): Drzewa i krzewy ozdobne w 21 parkach wiejskich Wielkopolski. Rocznik Dendrologiczny 48: 111-130.

CZeKalski M. (2002): Drzewa i krzewy ozdobne w 10 parkach wiejskich Wielkopolski. Rocznik Dendrologiczny 50: 97-110.

CZeKalski M. (2012): Wybrane parki wiejskie Wielkopolski. Uprawa i Ochrona Drzew 28: 1-54. 
Czekalski M. (2013): Dendroflora wybranych parków wiejskich Wielkopolski. Uprawa i Ochrona Drzew 31: 11-53.

DurCZYKIEWICZ L. (1912): Dwory polskie w Wielkiem Księstwie Poznańskiem. Poznań; Nakładem L. Durczykiewicza w Czempiniu.

KonDRACKI J. (2002): Geografia regionalna Polski. Wydawnictwo Naukowe PWN, Warszawa.

RozPORZĄDZENIE Ministra Środowiska z dnia 4 grudnia 2017 r. w sprawie kryteriów uznawania tworów przyrody żywej i nieożywionej za pomniki przyrody. (2017). Dz.U. 2017, poz. 2300.

Seneta W., Dolatowski J. (2003): Dendrologia, Wydawnictwo Naukowe PWN, Warszawa.

Serwis Internetowy Wojewódzkiej Biblioteki Publicznej i Centrum Animacji Kultury w Poznaniu „Re- gion Wielkopolska" https://regionwielkopolska. $\mathrm{pl} /$ katalog-obiektow/palac-w-siedlcu.html (dostęp: 3.11.2018).

WILANOWSKi P. (1998): Inwentaryzacja dendrologiczna parku zabytkowego w Siedlcu. Wydruk komputerowy, przechowywany u obecnych właścicieli parku w Siedlcu.

Woś A. (1994): Klimat Niziny Wielkopolskiej. Wydawnictwo Naukowe UAM, Poznań.

For citation: AntKowiak W., CzeKalski M. (2018): Dendroflora parku pałacowego w Siedlcu (województwo wielkopolskie). Steciana 22, 3: 57-68. doi: 10.12657/steciana.022.008 